\title{
Karakterisasi Unjuk Kerja Diesel Engine Generator Set Sistem Dual Fuel Solar-Syngas Hasil Gasifikasi Briket Municipal Solid Waste (MSW) Secara Langsung
}

\author{
Achmad Rizkal Dan Bambang Sudarmanta \\ Jurusan Teknik Mesin, Fakultas Teknologi Industri, Institut Teknologi Sepuluh Nopember (ITS) \\ Jl. Arief Rahman Hakim, Surabaya 60111 Indonesia \\ e-mail: sudarmanta@me.its.ac.id
}

\begin{abstract}
Abstrak-Sejalan dengan semakin banyaknya kebutuhan energi untuk dapat digunakan sebagai bahan bakar maka perlu adanya pengembangan gas biomassa sebagai bahan bakar alternatif pada motor pembakaran dalam maka akan dilakukan penelitian mengenai aplikasi sistem dual fuel gas hasil gasifikasi biomassa municipal solid waste $(M S W)$ pada sistem downdraft dengan minyak solar pada motor diesel stasioner. Penelitian ini bertujuan untuk mengetahui seberapa besar solar yang tersibtitusi dengan adanya penambahan syngas yang disalurkan secara langsung. Penelitian ini dilakukan secara eksperimental dengan proses pemasukan aliran syngas yang dihasilkan downdraft Municipal Solid Waste (MSW) kedalam saluran udara mesin diesel generator set secara langsung menggunakan sistem mixer. Pengujian dilakukan dengan putaran konstan 2000 rpm dengan pembebanan bervariasi dari 200 watt sampai dengan 2000 watt dengan interval 200 watt. Bahwa produksi syngas dari reaktor gasifikasi ditambahkan sistem bypass untuk mengetahui kesesuaian antara reaktor gasifikasi dan mesin generatorset data $\dot{m}$ syngas yang dibutuhkan mesin diesel, m syngas yang di bypass untuk mendapatkan kesesuaian antara produksi syngas dan yang di bypass. Data-data yang diukur dari penelitian ini menunjukkan bahwa besar nilai mass flowrate gas syngas yang dibutuhkan mesin diesel pada AFR reaktor gasifier 1,39 sebesar $0,0003748 \mathrm{~kg} / \mathrm{s}$. Mass flowrate gas syngas yang di bypass menunjukkan nilai 0 pada saat sistem dijalankan karena seluruh gas syngas masuk kedalam ruang bakar. AFR rata-rata sebesar 14,54, Nilai Spesific Fuel Consumption (SFC) mengalami peningkatan $68 \%$ dari kondisi standar single fuel, Nilai efesiensi thermal mengalami kenaikan sebesar $7 \%$ dari kondisi single fuel, Nilai daya rata-rata sebesar $2,28 \mathrm{~kW}$, Nilai torsi rata-rata sebesar 10,94 N.m. Solar yang tersibtitusi sebesar $48 \%$. Nilai temperatur (coolant, mesin, oil, dan gas buang) pada setiap pembebanan mengalami kenaikan.
\end{abstract}

Kata Kunci-Motor diesel, sistem dual-fuel, syngas, minyak solar, municipal solid waste (msw), gasifikasi downdraft.

\section{PENDAhULUAN}

$M$ unicipal Solid Waste (MSW) atau sampah padatan perkotaan adalah jenis sampah umum yang mencakup sampah rumah tangga, sampah badan komersil, sampah di area-area umum dan ada kalanya sampah hasil treatement plant site yang dikumpulkan municipality dalam wilayah tertentu . Metode Gasifikasi merupakan salah satu metode yang dapat memanfaatkan sampah rumah tangga tersebut agar dapat menjadi sumber energi yang dapat dimanfaatkan. Gasifikasi adalah suatu proses perubahan bahan bakar padat secara termokimia menjadi gas, di mana udara yang diperlukan lebih rendah dari udara yang digunakan untuk proses pembakaran. Gas ini mempunyai sifat mudah terbakar yang kemudian dapat digunakan sebagai bahan bakar pada motor pembakaran dalam.

Diesel Dual Fuel (DDF) adalah mesin standar diesel yang ditambahkan bahan bakar lain pada intake manifold dan penyalaan bahan bakar dilakukan oleh semprotan solar yang disebut pilot fuel. Aplikasi syngas dengan sistem dual fuel pada mesin diesel dapat meningkatkan unjuk kerja dan efisiensi mesin dengan nilai subtitusi solar dan syngas mencapai 60\%., Sudarmanta [3].

Teknologi aplikasi sistem dual fuel ada 3 macam, Low Pressure Injected Gas (LPIG), High Pressure Injected Gas (HPIG), dan Combustion Air Gas Integration. Pada eksperimen ini kami menggunakan, Combustion Air Gas Integration. Model ini bekerja dengan mencampur udarabahan bakar gas sebelum memasuki saluran isap atau sebelum memasuki kompresor-turbocharger, apabila mesin diesel yang digunakan adalah turbocharged system. Sistem pencampuran dilakukan dengan alat yang dinamakan mixer yang diletakkan pada saluran isap mesin diesel. Keuntungan dari pemakaian sistem seperti ini antara lain murah secara ekonomis dibandingkan kedua sistem sebelumnya karena tidak menggunakan injektor maupun pompa bertekanan tinggi, tidak membutuhkan model yang rumit sehingga apabila suplai gas habis atau tersendat sistem akan langsung bekerja dengan $100 \%$ bahan bakar diesel. Sementara kerugian dari sistem ini adalah adanya kemungkinan gas sebagian keluar bersama gas buang pada saat katup isap dan buang terbuka bersamaan.

Dari penelitian yang dilakukan oleh, Suliono [4] dengan sistem dual-fuel, syngas hasil serbuk kayu dan solar dengan mekanisme mengkopel langsung dan by pass saluran syngas dengan mixer. Hasil unjuk kerja dari penelitian menunjukkan bahwa dengan penambahan syngas yang keluar dari hasil produksi gasifier dapat menghemat pemakaian solar sebesar $39 \%$ pada pembebanan 2400 watt. Nilai Specific Fuel Consumption (SFC) mengalami peningkatan $0,910 \mathrm{~kg} / \mathrm{hp} . \mathrm{h}$ dibandingkan dengan nilai single fuel. Serta nilai efesiensi thermal mengalami penurunan $12 \%$ terhadap nilai single fuel. 
Berdasarkan uraian di atas yang menjelaskan penggunaan syngas pada diesel dual fuel maka dilakukan penelitian lebih lanjut mengenai karakterisasi unjuk kerja sistem dual fuel gasifier downdraft dengan umpan yang berasal dari briket munipical solid waste $(M S W)$ dan diesel engine generator set $3 \mathrm{KW}$. Sehingga diharapkan dapat mensinkronisasikan antara kebutuhan syngas sistem dual fuel terhadap produksi dari reaktor gasifikasi secara langsung (kompac). Apabila massa syngas yang masuk kedalam ruang bakar semakin banyak maka akan mengurangi massa udara yang masuk ke ruang bakar, sehingga $A F R$ menurun sehingga pembakaran menjadi tidak sempurna. Dalam penelitian ini dilakukan variasi pada pembebanan (listrik) untuk mengetahui pengaruhnya terhadap karakteristik unjuk kerja duel fuel, sehingga diharapkan mampu mendapatkan karakter terbaik syngas dari gasifier downdraft.

\section{URAIAN PENELITIAN}

\section{A. Teori Mesin Diesel}

Mesin diesel bekerja dengan menghisap udara luar murni, kemudian dikompresikan sehingga mencapai tekanan dan temperatur yang tinggi. Sesaat sebelum mencapai TMA, bahan bakar diinjeksikan dengan tekanan yang sangat tinggi dalam bentuk butiran-butiran halus dan lembut. Kemudian butiran-butiran lembut bahan bakar tersebut bercampur dengan udara bertemperatur tinggi dalam ruang bakar dan menghasilkan pembakaran, Kawano [1].

Proses pembakaran pada mesin diesel memiliki beberapa tahapan yang digambarkan dalam diagram P- $\theta$ seperti pada gambar 1. Tahapan pembakarannya, Kawano [1] yaitu:

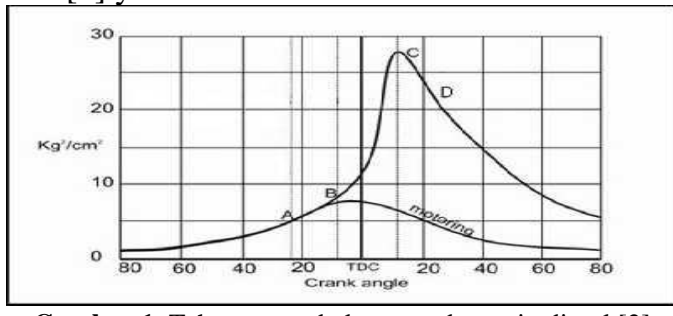

Gambar 1. Tahapan pembakaran pada mesin diesel [2]

\section{1) Tahap Pertama}

Ignition delay period yakni waktu dimana bahan bakar siap terbakar namun belum dinyalakan. Ignition delay dihitung dari awal injeksi sampai titik dimana pada kurva p- $\theta$ berpisah dengan kurva tekanan udara saja. Delay period ditunjukan oleh titik A-B.

\section{2) Tahap kedua}

Rapid atau uncrolled combustion (dapat digolongkan sebagai pre-mixed flame) terjadi setelah pengapian. Dalam tahap kedua ini kenaikkan tekanan cepat karena selama dalam periode tunda butiran lembut bahan bakar telah mempunyai waktu untuk menyebarkan dirinya sendiri pada daerah yang luas dan mereka telah mendapatkan udara segar disekelilingnya. Periode rapid atau uncontrolled combustion dihitung mulai dari akhir dari periode tunda sampai dengan tekanan tertinggi pada diagram indikator. Kira-kira sepertiga dari panas terlibat sampai tahap ini.

\section{3) Tahap Ketiga}

Conontrolled combustion, periode kedua dari rapid atau uncontrolled combustion diikutioleh tahap ketiga yakni controlled combustion. Pada akhir tehap kedua temperatur dan tekanan membuat butiran lembut bahan bakar yang terinjeksikan pada tahap akhir injeksi terbakar seketika, dan kenaikkan tekanan dapat dikontrol dengan cara mekanisme murni yakni pengaturan laju injeksi. Periode controlled combustion diasumsi sampai akhir pada temperatur maksimum siklus. Panas yang terlibat sampai akhir controlled combustion sekitar $70 \%$ $80 \%$ dari total panas dari bahan bakar yang disuplai selama siklus.

\section{4) Tahap Kempat}

Tahap keempat ini tidak terjadi pada semua kasus pembakaran pada motor CI, After burning. Secara teoritis diharapkan proses pembakaran berakhir setelah selesainya tahap ketiga. Namun karena distribusi partikel bahan bakar kurang baik, pembakaran berlanjut pada sisa langkah ekpansi. Dari itulah nama after burning atau tahap keempat dikembangkan. Panas total yang terlibat sampai akhir pembakaran adalah 95\%-97\% sedangkan sisa panas, 3\%-5\% keluar ke sistem ekshause sebagai unbrunt fuel.

\section{B. Prinsip Kerja Sistem Dual Fuel}

Bahan bakar gas ini dicampur dengan udara dalam silinder mesin baik melalui pencampuran langsung di intake manifold dengan udara atau melalui suntikan langsung ke dalam silinder. Sebuah mesin dual fuel pada dasarnya adalah mesin diesel yang dimodifikasi di mana bahan bakar gas, disebut bahan bakar utama, yang dicampur bersama dengan udara dengan menggunakan mixing yang berbentuk venturi yang akan masuk melalui intake manifold. Bahan bakar ini adalah sumber utama energi input ke mesin. Bahan bakar gas utama dikompresi dengan udara, bahan bakar gas memiliki temperatur terbakar sendiri lebih tinggi dibandingkan minyak solar. Sedangkan bahan bakar diesel, biasanya disebut pilot fuel, di injeksi seperti pada mesin diesel biasa di dekat akhir kompresi primer campuran bahan bakar udara. Bahan bakar pilot diesel merupakan yang melakukan pengapian pertama dan bertindak sebagai sumber pengapian untuk pembakaran dari campuran bahan bakar udara gas. Bahan bakar pilot diesel, yang dinjeksi ke ruang bakar hanya menyumbang sebagian kecil dari tenaga mesin yang dihasilkan.

\section{Governer pada Mesin Diesel}

Governor adalah komponen pada motor bakar yang berfungsi untuk mengontrol putaran mesin dengan cara mengendalikan jumlah bahan bakar yang diberikan sehingga putarannya dapat dipertahankan tetap stabil tanpa tergantung kondisi pembebanan. Contoh umum dari mekanisme governor adalah governor sentrifugal atau dikenal sebagai watt governor atau fly-ball governor, model ini menggunakan bandul yang dipasang pada lengan yang berpegas.

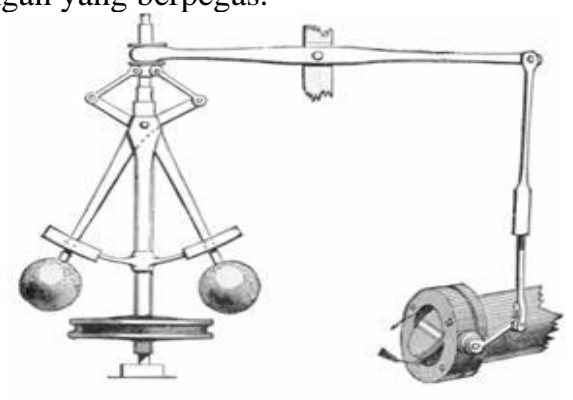

Gambar 2. Governor sentrifugal 


\section{Metode Penelitian dan Alat Uji}

\section{A. Metode Penelitian}

Pengujian dilakukan pada mesin diesel constant speed electrical dynamometer. Pengujian dilakukan pada mesin sebagai alat uji dengan poros utama yang telah terkopel langsung dengan electrical generator sebagai electrical dynamometer. True experimental method pada penelitian ini dibagi atas 2 (dua) kelompok, yaitu:

1. Kelompok kontrol adalah mesin diesel menggunakan minyak solar,

2. Kelompok uji adalah mesin diesel menggunakan dual-fuel system.

\section{B. Alat Uji}

Alat uji yang digunakan dalam penelitian ini antara lain sebagai berikut :

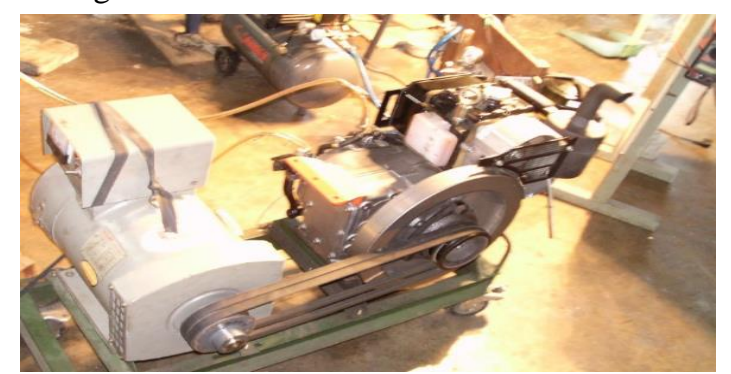

Gambar 3. Satu set engine diesel (Yanmar)-Generator (Noqiwa)

1) Mesin diesel dengan spesifikasi :
- Merk
: Yanmar
- Model
: TF $55 \mathrm{R}$

- Sistem pembakaran: direct injection

2) Generator listrik / electrical dynamometer dengan spesifikasi :

- Merek : Noqiwa

- Model : ST-3

\section{Skema Percobaan}

Percobaan ini dilakukan untuk mendapatkan $\mathrm{AFR}_{\text {mesin }}$ yang baik, agar bahan bakar yang digunakan dapar terbakar dengan sempurna. Dan mengurangi konsumsi solar dengan adanya sistem dual fuel tersebut.

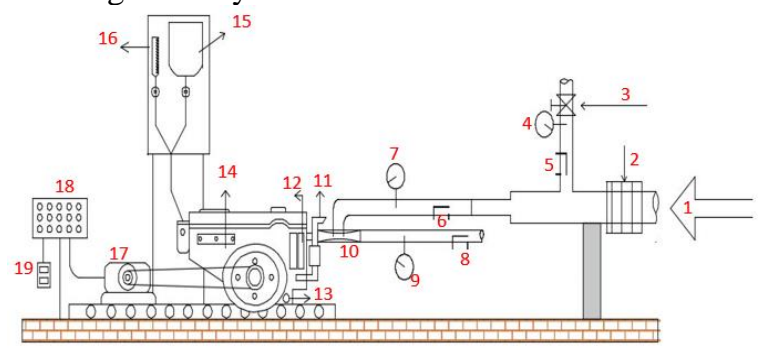

Gambar 4. Skema percobaan

\section{Keterangan}

1. Gas syngas hasil gasifier

2. Saringan syngas

11. Temperatur gas buang

3. Valve syngas yang dibypass

12. Temperatur Pendingin

5. Pitot tube syngas yang di bypass 14. Temperatur mesin

5. Pitot tube syngas yang di bypass 15. Tank solar

6. Pitot tube syngas yang ke mesin 16. Gelas ukur

7. Flowmeter syngas ke mesin 17. Generator set

8. Pitot tube udara ke mesin

18. pembebanan

9. Flowmeter udara ke mesin

19. Voltage dan ampere

\section{Rancangan Eksperimen}

TABEL 3.1 PARAMETER EKSPERIMEN

\begin{tabular}{|c|c|c|c|c|}
\hline \multicolumn{3}{|c|}{ Parameter Input } & \multicolumn{2}{|c|}{ Parameter Output } \\
\hline \multirow{2}{*}{ Konstan } & \multicolumn{2}{|c|}{ Bervariasi } & \multirow{2}{*}{ Diukur } & \multirow{2}{*}{ Dihitung } \\
\hline & $\begin{array}{l}\text { AFR }_{\text {gasifier }} \\
\text { (n) }\end{array}$ & Beban Listrik & & \\
\hline $\begin{array}{l}- \text { - Type } \\
\text { generator set } \\
\text { mesin Diesel } \\
\text { - Putaran mesin } \\
\text { diesel 2000 } \\
\text { rpm } \\
\text { - Bahan bakar: }\end{array}$ & $\begin{array}{l}\text { - AFRgasifier } 1 \\
=\end{array}$ & $\begin{array}{l}- \text { Pembebanan } \\
\text { listrik 200W- } \\
2000 \mathrm{~W} \text { dengan } \\
\text { interval } 200 \mathrm{~W}\end{array}$ & $\begin{array}{l}\text { - t konsumsi } \\
\text { bahan bakar } \\
\text { solar } 25 \mathrm{ml} \\
- \text { m masuk pada } \\
\text { intake } \\
\text { - } \dot{m} \text { syngas yang } \\
\text { Bypass }\end{array}$ & $\begin{array}{l}\text { - Unjuk kerja } \\
\text { mesin diesel } \\
\text { dual fuel : Daya, } \\
\text { torsi, bmep, sfc, } \\
\text { dan effisiensi. } \\
\text { - AFR mein } \\
\text { - Solar tersibtitusi }\end{array}$ \\
\hline $\begin{array}{l}\text { syngas dan } \\
\text { solar } \\
\text { - Metode } \\
\text { pemasukan } \\
\text { syngas dengan } \\
\text { mixer. }\end{array}$ & $\begin{array}{l}\text { - AFRgasifier } 2 \\
=\ldots\end{array}$ & $\begin{array}{l}\text { Pembebanan } \\
\text { listrik 200W- } \\
2000 \mathrm{~W} \text { dengan } \\
\text { interval 200W }\end{array}$ & $\begin{array}{l}\text { - mi udara } \\
\text { - Suhu } \\
\text { Operational: } \\
\text { Tair pendingin, } \\
\text { Tudara, } T_{\text {sygngas, }}\end{array}$ & \\
\hline $\begin{array}{l}\text { - Volume gelas } \\
\text { ukur bahan } \\
\text { bakar solar } 25 \\
\text { ml }\end{array}$ & $\begin{array}{l}- \text { AFRgasifier } 3 \\
\quad=\ldots\end{array}$ & $\begin{array}{l}\text { - Pembebanan } \\
\text { listrik 200W- } \\
2000 \mathrm{~W} \text { dengan } \\
\text { interval 200W }\end{array}$ & $\begin{array}{l}\text { Tgas buang } \\
\text { dan Toli pelumas } \\
\text { - Beban : Volt } \\
\text { dan Arus }\end{array}$ & \\
\hline
\end{tabular}

IV.

HASIL DAN ANALISA

Berdasarkan hasil uji kandungan yang ada dalam gas yang berasal dari briket municipal solid waste adalah sebagai berikut:

TABEL 4.1 TABEL BESARNYA KOMPOSISI KANDUNGAN SYNGAS YANG BERASAL DARI BRIKET MUNICIPAL SOLID WASTE (MSW).PADA AFR REAKTOR 0,72 ; DT $15 \%$.

\begin{tabular}{|c|c|c|c|}
\hline Komposisi & $\begin{array}{c}\text { Persentase } \\
\text { volume } \\
(\%)\end{array}$ & $\begin{array}{c}\rho\left(\mathrm{Kg} / \mathrm{m}^{3}\right), \mathrm{pada} \\
\mathrm{T}=305 \mathrm{~K}[15]\end{array}$ & $\begin{array}{c}\mu\left(10^{-5} \mathrm{~Pa} \mathrm{~S}\right), \\
\text { pada } \mathrm{T}=20^{\circ} \mathrm{C} \\
{[15]}\end{array}$ \\
\hline $\mathrm{CO}$ & 7,99 & 1,087 & 1,74 \\
\hline $\mathrm{H}_{2}$ & 7,60 & 0,078 & 0,88 \\
\hline $\mathrm{CH}_{4}$ & 0,04 & 0,502 & 0,99 \\
\hline $\mathrm{CO}_{2}$ & 6,74 & 1,722 & 1,47 \\
\hline $\mathrm{N}_{2}$ & 61,99 & 1,092 & 1,76 \\
\hline $\mathrm{O}_{2}$ & 15,65 & 1,248 & 2,04 \\
\hline
\end{tabular}

TABEL 4.2 TABEL NILAI HLV MASING-MASING VARIASI AFR REAKTOR DENGAN BESARAN DUTY CYCLE 15\%, 20\% DAN 25\%

\begin{tabular}{|c|c|c|c|c|c|}
\hline \multirow{3}{*}{$\begin{array}{l}\text { Duty } \\
\text { cycle }\end{array}$} & \multirow{3}{*}{$\begin{array}{c}\text { laju alir } \\
\text { massa udara }\end{array}$} & \multirow{4}{*}{\begin{tabular}{|c|}
$\begin{array}{c}\text { Nillai Kalor bawvah } \\
\text { (LHVi) gas yang terbakar }\end{array}$ \\
Air fuel ratio \\
(rasio udara \\
bahan bakar)
\end{tabular}} & \multirow{2}{*}{$\begin{array}{c}\text { Nilai Kalor bawah } \\
\text { (LHV) }\end{array}$} & \multirow{2}{*}{$\begin{array}{l}\text { Massa jenis } \\
\text { p Syn-gas } \\
\end{array}$} & \multirow{2}{*}{$\begin{array}{l}\text { Nilai Kalor } \\
\text { bawah (LHV) }\end{array}$} \\
\hline & & & & & \\
\hline & & & & & \\
\hline$(\%)$ & $(\mathrm{kg} / \mathrm{s})$ & & Syngas (kJ/m3) & $(\mathrm{kg} / \mathrm{m} 3)$ & Syngas (kJ/kg) \\
\hline 15 & 0,00018 & 0,72 & 3743,96 & 1,08 & 3463,81 \\
\hline 20 & 0,00052 & 1,04 & 3466,87 & 1,08 & 3747,00 \\
\hline 25 & 0,00085 & 1,39 & 3139,62 & 1,06 & 3321,64 \\
\hline
\end{tabular}

A. Hasil analisa Daya $(\mathrm{Ne})$

Grafik nilai daya di bawah mempunyai Trend nilai daya naik seiring dengan meningkatnya nilai beban yang diterima. Hal ini terjadi karena dengan bertambahnya beban listrik maka jumlah minyak solar yang diinjeksikan ke dalam ruang bakar akan lebih banyak untuk menjaga putaran engine konstan, karena pada saat beban listrik ditambah maka beban putaran generator bertambah berat dan putaran engine turun.

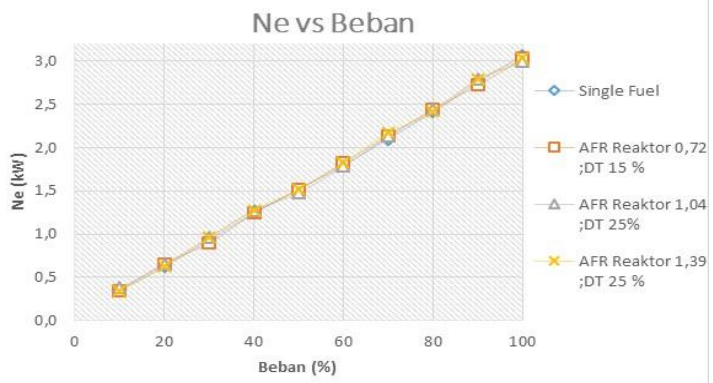

Gambar 5. Grafik Daya efektif fungsi beban listrik 
Pada grafik di atas terlihat kecenderungan bahwa tidak ada perbedaan nilai daya yang dihasilkan antara pengoperasian dual-fuel dan single-fuel. Hal ini disebabkan oleh karena pada pengoperasian dual-fuel, putaran mesin dijaga konstan untuk mendapatkan tegangan listrik yang stabil, dengan mengatur jumlah pasokan laju alir minyak solar dengan mekanisme governor. Laju alir massa bahan bakar gas yang masuk dijaga konstan. Sesuai dengan bukaan kran yang disularkan secara langsung menuju engine.

\section{B. Hasil analisa Torsi (Mt)}

Grafik torsi meningkat seiring dengan meningkatnya beban yang diterima mesin. Pada pengujian kali ini putaran mesin berputar secara stasioner, maka perubahan nilai torsi bergantung variasi daya efektif yang pada akhirnya bentuk grafik yang ditunjukkan sama dengan bentuk grafik yang ditunjukkan oleh grafik daya efektif fungsi beban listrik.

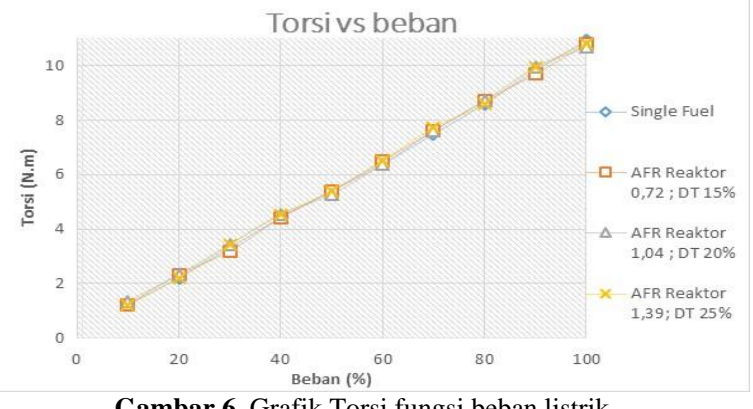

Gambar 6. Grafik Torsi fungsi beban listrik

Pada grafik ini didapatkan tidak ada perbedaan signifikan antara nilai torsi sistem single-fuel dan dualfuel, hal ini dikarenakan perubahan nilai arus dan tegangan yang dihasilkan oleh generator juga relatif kecil karena putaran mesin yang dijaga konstan di putaran 2000 rpm dengan melakukan kontrol pada pemasukkan bahan bakar minyak solar menggunakan mekanisme governor.

\section{Hasil analisa Brake Mean Effective Pressure (BMEP)}

Grafik bmep terlihat mempunyai kecenderungan linear naik seiring dengan bertambahnya beban. Apabila ditinjau dari fenomena yang terjadi di dalam mesin, kenaikan beban akan menyebabkan perubahan air-fuel ratio (AFR) ke arah campuran kaya bahan bakar. Semakin banyak bahan bakar yang diledakkan di ruang bakar, maka tekanan ekspansi yang dihasilkan juga akan semakin besar. Hal inilah yang menyebabkan terjadinya kenaikan BMEP seiring dengan kenaikan beban.

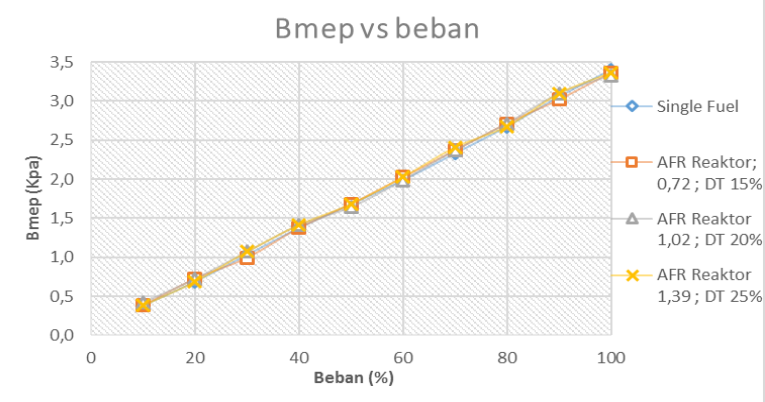

Gambar 7. Grafik Bmep fungsi beban listrik

Grafik juga menunjukkan tidak ada perbedaan tekanan rata-rata yang signifikan antara sistem single fuel dan dual fuel, hal ini disebabkan perubahan nilai arus dan tegangan yang dihasilkan oleh generator juga relatif kecil karena putaran mesin yang dijaga konstan di putaran $2000 \mathrm{rpm}$.

\section{Hasil analisa Konsumsi Bahan Bakar Spesifik (sfc)}

Grafik dibawah secara umum menunjukkan bahwa nilai SFC semakin turun seiring dengan penambahan beban yang semakin tinggi, hal ini menunjukkan bahwa semakin besar beban yang diterima mesin, bahan bakar yang diperlukan akan semakin meningkat. Hal ini disebabkan karena dengan bertambahnya beban listrik maka jumlah minyak solar yang diinjeksikan ke dalam ruang bakar akan lebih banyak untuk menjaga putaran engine konstan, karena pada saat beban listrik ditambah maka beban putaran generator bertambah berat dan putaran engine turun.

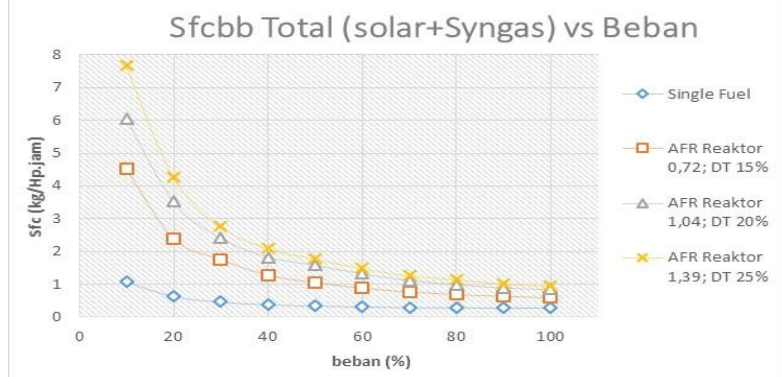

Gambar 8. Grafik SFC Total dual fuel fungsi beban listrik

Demikian pula saat penggunaan syngas, ketika konsumsi syngas di jaga konstan untuk setiap pembebanan, mass flowrate syngas tidak berubah. Dengan penambahan mass flow syngas akan mengakibatkan waktu yang diperlukan untuk konsumsi minyak solar semakin lama. Namun, seiring dengan penambahan beban dan mass flowrate syngas yang konstan, waktu konsumsi solar akan menurun. Sehingga nilai $s f c$ menurun dengan penambahan beban, pada tekanan yang sama. Untuk pembebanan yang sama, nilai sfc semakin turun dengan bertambahnya tekanan syngas. Hal ini disebabkan karena dengan penambahan syngas akan menyebabkan mass flowrate syngas naik dan mass flowrate solar semakin kecil.

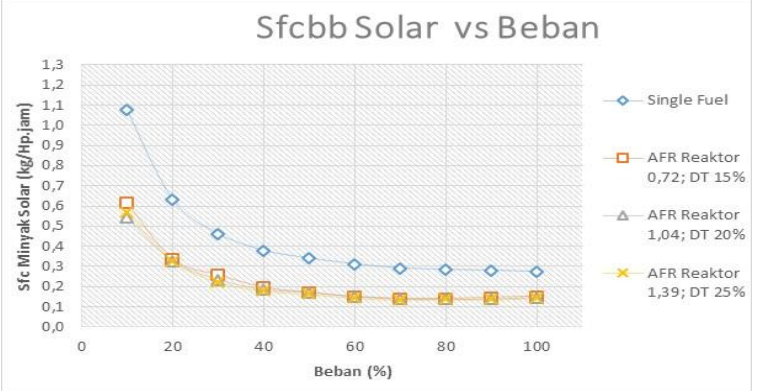

Gambar 9. Grafik $S F C$ solar fungsi beban listrik

Pada gambar diatas ditunjukkan perbandingan konsumsi bahan bakar spesifik minyak solar saja untuk single-fuel dan pada saat dual-fuel dioperasikan. Dari grafik tersebut dapat dilihat bahwa secara umum konsumsi minyak solar dual mengalami penurunan dari kondisi berbahan bakar solar single. Dengan adanya penambahan jumlah syngas yang masuk ke dalam ruang bakar melalui variasi mass flow rate syngas, berarti jumlah syngas yang masuk ke ruang bakar dapat menggantikan sejumlah bahan bakar minyak solar untuk mendapatkan daya yang dibutuhkan untuk mengatasi beban listrik 


\section{E. Hasil analisa Bahan Bakar Solar Tersibtitusi}

Pada gambar diatas dapat dilihat jumlah persentase minyak solar yang digantikan oleh syngas setiap penambahan syngas dan beban listrik. Setiap kenaikan laju alir massa syngas, maka besarnya jumlah persentase minyak solar yang diinjeksikan ke dalam ruang bakar untuk menjaga putaran mesin konstan akan semakin turun. Sehingga jumlah persentase minyak solar yang digantikan akan semakin besar.

Saat beban listrik semakin besar, jumlah minyak solar semakin banyak untuk menjaga putaran konstan sehingga persentase pergantian semakin kecil.

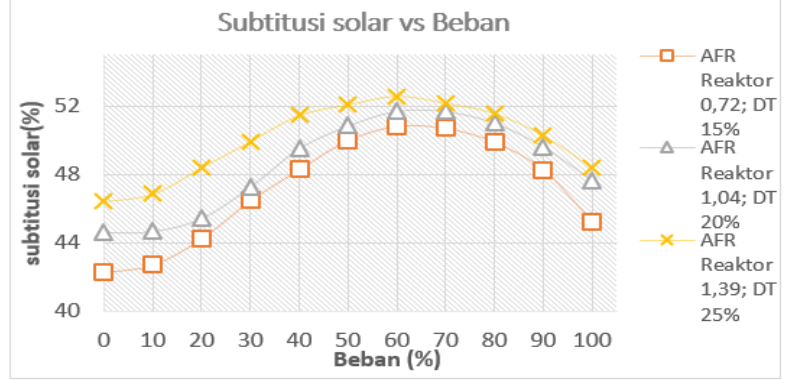

Gambar 10. Grafik subtitusi solar fungsi beban listrik

Pada grafik tersebut terlihat bahwa jumlah persentase penggantian minyak solar yang terbesar terjadi pada duty cycle $25 \%$ pada pembebanan $60 \%$. Hal ini disebabkan syngas menjalani perannya sebagai secondary fuel dengan baik, meskipun perannya tidak dapat menggantikan minyak solar $100 \%$.

\section{F. Hasil analisa rasio udara-bahan bakar}

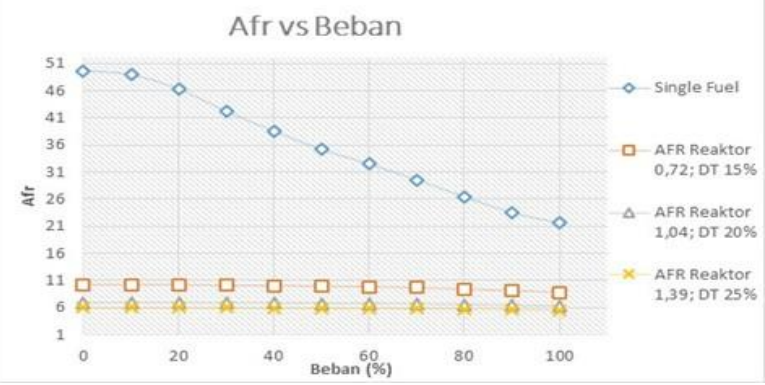

Gambar 11. Grafik AFR fungsi beban listrik

Pada setiap penambahan mass flow rate syngas menunjukan trend grafik yang menurun. Bertambahnya beban listrik menyebabkan AFR berkurang karena pada ruang bakar bahan bakar menjadi semakin kaya dan kekurangan asupan udara sehingga bahan bakar tercampur tidak stokiometri, hal ini disebabkan untuk mengatasi pertambahan beban, mesin harus menghasilkan daya yang besar pula. Daya yang membesar ini dihasilkan dari pembakaran bahan bakar yang sempurna antara campuran udara dan bahan bakar .

\section{G. Hasil analisa Efisiensi Termal $\left(\eta_{\text {th }}\right)$.}

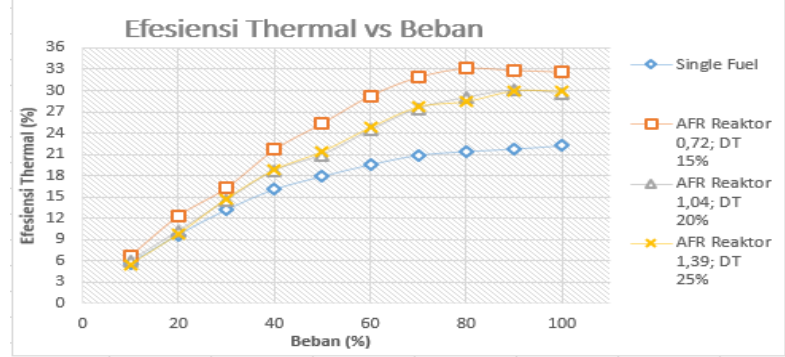

Gambar 12. Grafik Efesiensi thermal fungsi beban listrik
Dapat dilihat bahwa faktor yang membuat nilai efisiensi termal semakin naik adalah nilai laju alir massa syngas, nilai ini mempengaruhi nilai effisiensinya yang semakin naik. Dan nilai dari LHV mass flowrate syngas yang rendah dan $L H V$ solar dengan mass flowrate yang tinggi mengakibatkan nilai pembanding dari rumus diatas mengalami kenaikan. Hal ini dapat terlihat pada duty cycle $15 \%$ sampai dengan $25 \%$ yang mengalami kenaikan effisiensi thermal, sehingga pembakaran cukup optimal. Karena mesin diesel memiliki efesiensi thermal rata-rata diatas $30 \%$.

\section{H. Hasil analisa Jumlah Energi per Siklus}

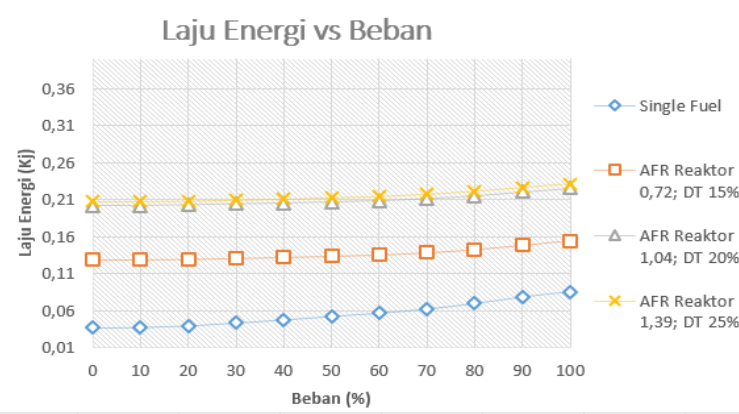

Gambar 13. Grafik Laju energi Per siklus fungsi beban listrik

Dari grafik ini pula didapatkan nilai laju energi pada pengoperasian dual fuel lebih tinggi dibandingkan pengoperasian single fuel. Hal ini disebabkan untuk setiap siklus pada setiap daya yang sama dengan adanya penambahan gas menyebabkan proses pencampuran bahan bakar menjadi lebih baik, sehingga untuk setiap siklus yang sama kebutuhan energi yang digunakan untuk proses pembakaran menjadi lebih baik untuk pembebanan yang sama pada setiap siklusnya .

I. Analisa Temperatur Engine, Air pendingin, Oli dan Gas buang
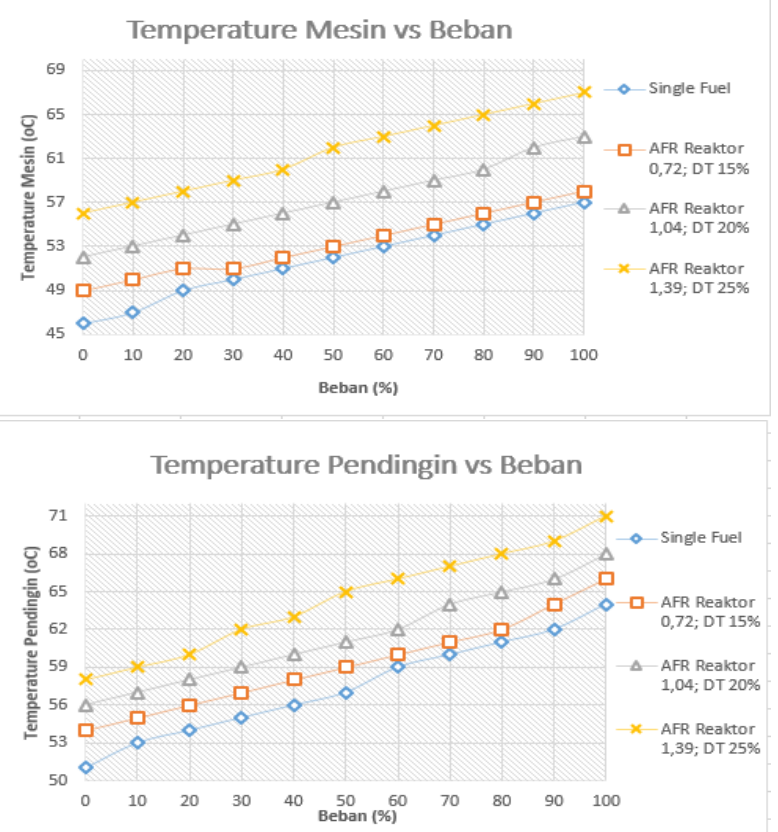


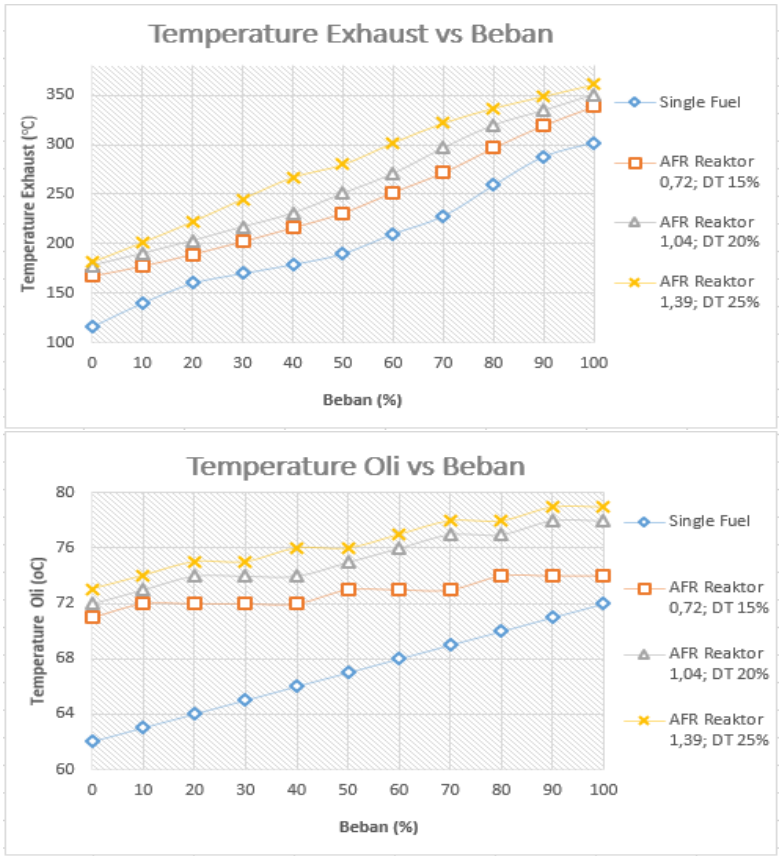

Gambar 14. Grafik Temperatur fungsi beban listrik

Gambar diatas menunjukkan grafik temperatur engine, pendingin, oli dan gas buang terhadap beban. Semua kondisi grafik pada gambar diatas memiliki tren yang sama, yaitu terjadi kenaikan temperatur seiring beban mesin. Semakin meningkatnya beban maka jumlah bahan bakar yang masuk ke ruang bakar akan semakin banyak, sehingga panas pembakaran yang dilepas ke dinding silinder juga semakin banyak, sehingga temperatur engine pun naik. Dan ketika dimasukkan bahan bakar syngas maka nilai dari $L H V$ bahan bakar menjadi naik yang mengakibatkan pembakaran diruang bakar menjadi lebih besar, maka pelepasan kalor akan menjadi lebih besar.

\section{KESIMPULAN}

Unjuk kerja diesel engine generator set yang dioperasikan menggunakan dual fuel mengalami perubahan dibandingkan dengan single fuel. Perubahanperubahan tersebut antara lain:

- Daya, Torsi dan BMEP mengalami penurunan dibandingkan single fuel, jika pada single fuel ( daya $=2,28$; Torsi $=10,94$; dan BMEP $=3,40$ ) maka pada dual fuel yaitu ( Daya $=2,24$; Torsi $=10,69$; dan $\mathrm{BMEP}=3$,).
- Untuk SFC pada dual fuel mengalami peningkatan jika dibandingkan dengan single fuel, yaitu sebesar $0,95 \mathrm{~kg} / \mathrm{Hp} . \mathrm{h}$ maka pada single fuel adalah 0,277 $\mathrm{kg} / \mathrm{Hp} . \mathrm{h}$.

- Untuk efisiensi thermal mengalami kenaikan, jika pada single fuel sebesar 22,26\% maka pada dual fuel sebesar $29,92 \%$.

Dengan mekanisme mengkopel langsung dan by pass saluran syngas dengan mixer yang dipasang pada saluran hisap memungkinkan mekanisme dual fuel dapat bekerja secara langsung tanpa penyimpanan syngas terlebih dahulu pada tabung bertekanan.

- Dengan menggunakan bahan bakar ganda pada mesin diesel dual fuel Dapat menghemat solar jika menggunakan syngas pada mesin diesel dual fuel yaitu sebesar rata-rata pada setiap variasi AFR Reaktor dengan duty cycle 15 sampai dengan $25 \%$ Yaitu sebesar $48 \%$.

\section{UCAPAN TERIMA KASIH}

Penulis, Achmad Rizkal, mengucapkan terima kasih kepada dosen pembimbing dan pembahas yang telah memberikan kritik dan saran untuk penulisan artikel ini. Penulis Juga mengucapkan terima kasih kepada keluarga besar penulis yang memberikan dukungan baik secara moral dan finansial dalam penyusunan paper ini.

\section{DAFTAR PUSTAKA}

[1] Kawano, D. Sungkono. 2014. Motor Bakar Torak (Diesel). Jurusan Teknik Mesin FTI-ITS, Surabaya.

[2] Mathur, M.L.,\& Sharma, R.P. 1980. A Course in Internal Combustion Engine $3^{\text {rd }}$ edition, Dhanpat Rai \& Sons, Nai Sarak, Delhi.

[3] Sudarmanta, Bambang,. 2015. Dual Fuel Engine Performance Using Biodiesel and Syn-Gas from Rice Husk Downdraft Gasification for Power Generation. International Seminar, Mechanical Engineering Department, Faculty of Technology Industry, Sepuluh Nopember Institut of Technology Surabaya, Indonesia.

[4] Suliono. 2015. Karakterisasi Unjuk Kerja Sistem Dual Fuel Gasifier Downdraft Serbuk Kayu dan Diesel Engine Generator Set $3 \mathbf{K} \boldsymbol{W}$. Tesis. Jurusan Teknik Mesin ITS, Surabaya.

[5] N.Tippawong, A., Promwungkwa, P., Rerkkriangkrai. 2006. Long-term Operation of A Small Biogas/Diesel Dual-Fuel Engine for On-Farm Electricity Generation, Chiang Mai University, Thailand. 